\title{
Genetic variations associated with brain disorders: Focus on synaptic plasticity and apoptosis regulatory genes in schizophrenia, posttraumatic stress disorder and ischemic stroke
}

\author{
Anna Boyajyan, Ani Stepanyan, Diana Avetyan, Hovsep Ghazaryan, Sofi Atshemyan, \\ Roksana Zakharyan, Kristina Pirumyan, Gohar Tsakanova
}

Laboratory of Human Genomics and Immunomics, Department of Applied Molecular Biology, Institute of Molecular Biology NAS RA, Yerevan, Armenia

\section{Email address:}

aboyajyan@sci.am (A. Boyajyan), a_stepanyan@mb.sci.am (A. Stepanyan),imb@sci.am (D. Avetyan), h_ghazaryan@mb.sci.am (H. Ghazaryan), s_atshemyan@mb.sci.am (S. Atshemyan), r_zakharyan@mb.sci.am (R. Zakharyan), k_pirumyan@mb.sci.am (K. Pirumyan), natdep@sci.am (G. Tsakanova)

\section{To cite this article:}

Anna Boyajyan, Ani Stepanyan, Diana Avetyan, Hovsep Ghazaryan, Sofi Atshemyan, Roksana Zakharyan, Kristina Pirumyan, Gohar Tsakanova. Genetic Variations Associated with Brain Disorders: Focus on Synaptic Plasticity and Apoptosis Regulatory Genes in Schizophrenia, Posttraumatic Stress Disorder and Ischemic Stroke. International Journal of Genetics and Genomics. Vol. 2, No. 2, 2014, pp. 19-29. doi: 10.11648/j.ijgg.20140202.12

\begin{abstract}
Epidemiologic, clinical and experimental data indicates that a majority of brain disorders including schizophrenia (SCZ), posttraumatic stress disorder (PTSD), and ischemic stroke (IS) are multifactorial disorders with strong and complex genetic component. Identification of all genetic variations associated with these disorders may sufficiently contribute to understanding of their basic pathomechanisms and encourage development of new innovative approaches to their early diagnosis and treatment. The aim of this review article is to provide overview of our recent studies on evaluation of potential association of SCZ, PTSD and IS with functional single nucleotide polymorphisms (SNPs) of synaptic plasticity and apoptosis regulatory genes in Armenian population. Here, our attention was focused on genes encoding netrin G1 (NTNG1), brain-derived neurotrophic factor (BDNF), complexin-2 (CPLX2), nerve growth factor (NGF) and its receptor $(N G F R)$, annexin family proteins - annexin A5 and annexin A11 (ANXAV, ANXA11), and B-cell lymphoma 2 (Bcl-2) family proteins - Bcl-2 proper and Bcl-2-associated X protein (BCL2, BAX). Genomic DNA samples of diseased and healthy individuals were genotyped for a number of SNPs of the mentioned genes using polymerase chain reaction with sequence-specific primers (PCR-SSP). The significance of differences in genotype and allele frequencies and minor allele carriage between patients and healthy control subjects was determined using Pearson's Chi-square test. P-values less than 0.05 were considered statistically significant. Significant associations were found between: (1) SCZ and BDNF rs6265, $C P L X 2$ rs1366116, rs3892909, NGF rs6330, rs4839435, NGFR rs734194, rs11466155, rs2072446, ANXAV rs11575945, $B A X$ rs1057369 SNPs; (2) PTSD and CPLX2 rs1366116, BCL2 rs956572 SNPs; (3) IS and NTNG1 rs628117, CPLX2 rs1366116, ANXAV rs11575945 SNPs. The obtained results indicated the involvement of genetically determined alterations in synaptic plasticity and apoptosis in pathomechanisms of SCZ, PTSD and IS. The minor T allele of the CPLX2 gene rs1366116 polymorphism represents risk factor for all studied diseased conditions indicating important functional significance of this genetic variation in maintenance of synaptic plasticity. Another important conclusion of these studies is that minor alleles of some polymorphic variants of genes, encoding synaptic plasticity and apoptosis regulatory proteins, may play a protective role relative to SCZ decreasing the risk for development of this disorder. In summary, our studies emphasize the important contribution of changes in synaptic plasticity and apoptosis regulation to pathomechanisms of SCZ, PTSD, and IS as well as significant input of genetic factors to these changes.
\end{abstract}

Keywords: Schizophrenia, Posttraumatic Stress Disorder, Ischemic Stroke, Synaptic Plasticity, Apoptosis, Regulatory Genes, Single Nucleotide Polymorphisms, Genotyping, Association 


\section{Introduction}

Epidemiologic, clinical and experimental data indicates that a majority of brain disorders are multifactorial disorders with strong and complex genetic component [1-3]. Among those disorders are schizophrenia (SCZ) [4], posttraumatic stress disorder (PTSD) [5], and ischemic stroke (IS) [6]. All three disorders are severe diseased conditions and contribute significantly to disability and mortality of the human population worldwide [7-9]. Molecular pathomechanisms responsible for generation, progression and unfavorable clinical outcome of SCZ, PTSD and IS are only beginning to be understood, and currently available prognostic, diagnostic and treatment measures related to these disorders are not very efficient. Identification of all genetic variations associated with these disorders may sufficiently contribute to understanding of their basic pathomechanisms and encourage development of new innovative approaches to their early diagnosis and treatment. Several studies, including our own, suggest implication of alterations in synaptic neuronal plasticity and apoptosis to pathophysiology of SCZ, PTSD, and IS [10-19]. This review provides overview of our recent studies (including published [20-33] and unpublished data) on evaluation of potential association of SCZ, PTSD and IS with functional single nucleotide polymorphisms (SNPs) of synaptic plasticity and apoptosis regulatory genes. Here, our attention was focused on genes encoding netrin G1 (NTNG1), brain-derived neurotrophic factor (BDNF), complexin-2 (CPLX2), nerve growth factor (NGF) and its receptor $(N G F R)$, annexin family proteins - annexin A5 and annexin A11 (ANXAV, ANXA11), and B-cell lymphoma 2 (Bcl-2) family proteins - Bcl-2 proper and Bcl-2-associated $\mathrm{X}$ protein $(B C L 2, B A X)$. Genomic DNA samples of diseased and healthy individuals were genotyped for a number of SNPs of the mentioned genes using polymerase chain reaction with sequence-specific primers (PCR-SSP). Brief characteristics of selected genes and SNPs are given in Table 1 .

Table 1. Brief characteristics of selected genes and SNPS.

\begin{tabular}{|c|c|c|c|c|c|c|}
\hline \multicolumn{3}{|l|}{ Gene } & \multicolumn{4}{|l|}{ SNP } \\
\hline Name & ID & Location & ID & Substitution $^{+}$ & Position & Location (type) \\
\hline NTNG1 & 22854 & $1 \mathrm{p} 13.3$ & rs628117 & $\mathrm{A}>\mathrm{G}$ & 107997106 & intronic \\
\hline$B D N F$ & 627 & $11 \mathrm{p} 13$ & rs6265 & $\mathrm{G}>\mathrm{A}$ & 27679916 & exonic (missense) \\
\hline \multirow{2}{*}{$C P L X 2$} & \multirow{2}{*}{10814} & \multirow{2}{*}{$5 q 35.2$} & rs1366116 & $\mathrm{C}>\mathrm{T}$ & 175297531 & intronic ( $5^{\prime}$ near gene) \\
\hline & & & rs3892909 & $\mathrm{C}>\mathrm{T}$ & 175305591 & intronic \\
\hline \multirow{3}{*}{ NGF } & \multirow{3}{*}{4803} & \multirow{3}{*}{$1 \mathrm{p} 13.1$} & rs6330 & $\mathrm{G}>\mathrm{A}$ & 115829313 & exonic (missense) \\
\hline & & & rs4839435 & $\mathrm{G}>\mathrm{A}$ & 115858104 & intronic \\
\hline & & & rs11466155 & $\mathrm{C}>\mathrm{T}$ & 44942998 & exonic (synonymous) \\
\hline \multirow[t]{2}{*}{$N G F R$} & \multirow[t]{2}{*}{4804} & \multirow[t]{2}{*}{$17 q 21-q 22$} & rs2072446 & $\mathrm{C}>\mathrm{T}$ & 47587819 & missense \\
\hline & & & rs734194 & $\mathrm{T}>\mathrm{G}$ & 47591609 & 3'-UTR \\
\hline$A N X A V$ & 308 & $4 q 27$ & rs11575945 & $-1 \mathrm{C}>\mathrm{T}$ & 122617745 & Kozak sequence \\
\hline$A N X A 11$ & 311 & $10 q 21-23$ & rs1049550 & $\mathrm{G}>\mathrm{A}$ & 81916682 & missense \\
\hline$B A X$ & 581 & $19 q 13.33$ & rs1057369 & $\mathrm{A}>\mathrm{G}$ & 49464866 & intronic \\
\hline \multirow{2}{*}{$B C L 2$} & \multirow{2}{*}{596} & \multirow{2}{*}{$18 \mathrm{q} 21.33$} & rs956572 & $\mathrm{G}>\mathrm{A}$ & 60820571 & intronic \\
\hline & & & rs1801018 & $\mathrm{A}>\mathrm{G}$ & 60985879 & exonic (synonymous) \\
\hline
\end{tabular}

${ }^{+}$on forward strand.

\section{Methodology}

\subsection{Study Population}

Study subjects were chronic patients with paranoid form of SCZ and with PTSD of combat origin, patients with acute IS, and healthy individuals (HI) with no family or past history of any mental, cerebrovascular or cardiovascular disorders, as well as disorders characterized by alterations in apoptosis and synaptic plasticity. All subjects were Armenians born and living in Armenia. Both, the informed consents from all study subjects and the approval of the Ethics Committee of the Institute of Molecular Biology (IRB \#00004079) were received for these studies.

\subsection{Methods}

About $5 \mathrm{ml}$ of peripheral venous blood was collected from each study subject and transferred to EDTA-containing tubes. Genomic DNA samples were isolated from fresh blood according to a standard phenol-chloroform method [34] and stored at $-30^{\circ} \mathrm{C}$ until use. Using PCR-SSP method [35] DNA samples were genotyped for NTNG1 rs628117, BDNF rs6265, CPLX2 rs1366116, rs3892909, $N G F$ rs6330, rs4839435, NGFR rs11466155, rs2072446, rs734194, $A N X A V$ rs11575945, ANXA11 rs1049550, BAX rs1057369, $B C L 2$ rs956572, rs1801018 functional SNPs. The SNPs were selected based on either their functionality according to the National Center of Biotechnology Information (NCBI) databases (http://www.ncbi.nlm.nih.gov/) or tagging results obtained using the International HapMap Project database (http://hapmap.ncbi.nlm.nih.gov). All primers for PCR-SSP were designed using the genomic sequences in the GenBank nucleotide sequence database (https://www.ncbi.nlm. nih.gov/genbank/) and are indicated 
in Table 2. The presence/absence of allele-specific amplicons in the PCR products was visualized in $2 \%$ agarose gel stained with ethidium bromide fluorescent dye using DNA molecular weight markers as a reference. To check the reproducibility of results, randomly selected DNA samples (10\% of total) were genotyped twice.

\subsection{Data Analysis}

The distributions of genotypes for all investigated SNPs were checked for correspondence to the Hardy-Weinberg (H-W) equilibrium. In order to find potential relevance of the selected SNPs to SCZ, their genotype and allele frequencies and minor allele carriage rates in patients and HI were compared. The significance of differences in genotype and allele frequencies and minor allele carriage between patients and HI was determined using Pearson's Chi-square test. P-values less than 0.05 were considered statistically significant. P-values adjusted by Bonferroni multiple comparison correction are further indicated as $\mathrm{P}_{\text {corrected }}$, and those not adjusted - as $\mathrm{P}_{\text {nominal }}$.

Table 2. Primers designed for the selected SNPS.

\begin{tabular}{|c|c|}
\hline SNP & Nucleotide sequence of primers \\
\hline \multirow{3}{*}{ rs628117 } & standard allele: 5' ATCCTTGGAATGAAAGCCCA \\
\hline & minor allele: 5'- ATCCTTGGAATGAAAGCCCG \\
\hline & constant: 5'-TCACTGCCCTCTGTGTGCAGTG \\
\hline \multirow{3}{*}{ rs6265 } & standard allele: 5'- GGCTGACACTTTCGAACACG \\
\hline & minor allele: 5'- GGCTGACACTTTCGAACACA \\
\hline & constant: 5'- GTTACCCACTCACTAATACTG \\
\hline \multirow{3}{*}{ rs1366116 } & standard allele: 5'-ATGTGTAGGAAAATGGCTTCG \\
\hline & minor allele: 5'-ATGTGTAGGAAAATGGCTTCA \\
\hline & constant: 5'- CAATGGCCTCTGACTGGTG \\
\hline \multirow{2}{*}{ rs3892909 } & standard allele: 5'- GGTGAGGCTGCTGTCTGC \\
\hline & minor allele: 5'-GGTGAGGCTGCTGTCTGT \\
\hline
\end{tabular}

\begin{tabular}{|c|c|}
\hline SNP & Nucleotide sequence of primers \\
\hline \multirow{5}{*}{ rs6330 } & constant: 5'-CTGCTTCATGACGAAGTCCA \\
\hline & standard allele: 5'-GCATCTTGCTCTGTGCAGAT \\
\hline & minor allele: 5'-GACACACCATCCCCCAAGC \\
\hline & constant: 5'-GACACACCATCCCCCAAGT \\
\hline & standard allele: 5'-TGGGTGCCAAAAAGCTTGGC \\
\hline \multirow[t]{3}{*}{ rs4839435 } & minor allele: 5'-TGGGTGCCAAAAAGCTTGGT \\
\hline & constant: 5'-GCAGCTCCTGCAATTATCCA \\
\hline & standard allele: 5'-AGGCTATGTAGGCCACAAGG \\
\hline \multirow[t]{3}{*}{ rs 11466155} & minor allele: 5'-AGGCTATGTAGGCCACAAGA \\
\hline & constant: 5'-CAGAGGGCTCGGACAGCACA \\
\hline & standard allele: 5'-GTCCACACCCCCAGAGGGCTC \\
\hline \multirow[t]{2}{*}{ rs2072446 } & minor allele: 5'-GTCCACACCCCCAGAGGGCTT \\
\hline & standard allele: 5'-GCTGGAGCTGGCGTCTGTCT \\
\hline \multirow[t]{3}{*}{ rs734194 } & minor allele: 5'-GCTGGAGCTGGCGTCTGTCG \\
\hline & constant: 5'-CTAGAGCTGGGAGAAATCCC \\
\hline & standard allele: 5'-CCTGACCTGAGTAGTCGC C \\
\hline \multirow[t]{3}{*}{ rs 11575945} & minor allele: 5'-CCTGACCTGAGTAGTCGCT \\
\hline & constant: 5'-GCCACGTCACCAGCTGTTGC \\
\hline & standard allele: 5'-CTGCCGCTGCTTGTTGGAGCG \\
\hline \multirow[t]{3}{*}{ rs 1049550} & minor allele: 5'-CTGCCGCTGCTTGTTGGAGCA \\
\hline & constant: 5'-CACCCTCCAGGATGCCCTCATAT \\
\hline & standard allele: 5'-ATCTTCTTCCAGATGGTGAGT \\
\hline \multirow{3}{*}{ rs 1057369} & minor allele: 5'-ATCTTCTTCCAGATGGTGAGC \\
\hline & constant: 5'-TTACAGGTGTGAGCCACCATG \\
\hline & standard allele: 5'-AGAGGGAGTCATGACTGAATC \\
\hline \multirow[t]{3}{*}{ rs956572 } & minor allele: 5'-AGAGGGAGTCATGACTGAATT \\
\hline & constant: 5'-CAGATCTGTGCTTGAACCTCA \\
\hline & standard allele: 5'ATCTCCCGGTTATCGTACCCT \\
\hline \multirow[t]{2}{*}{ rs 1801018} & minor allele: 5'-ATCTCCCGGTTATCGTACCCC \\
\hline & constant: 5'-GATCCGAAAGGAATTGGAATA \\
\hline
\end{tabular}

\section{Results and Discussion}

The results of genotyping are presented separately for each diseased condition in Tables 3-5.

Table 3. Genotype, allele, and minor allele carriage frequencies of the selected SNPS in patients with SCZ and HI.

\begin{tabular}{|c|c|c|c|c|c|c|c|}
\hline \multirow{2}{*}{$\begin{array}{l}\text { SNP ID } \\
\text { rs628117 }\end{array}$} & \multicolumn{3}{|c|}{ Genotypes } & \multicolumn{2}{|c|}{ Alleles } & \multirow{2}{*}{$\begin{array}{l}\text { Carriage } \\
\mathrm{G}\end{array}$} & \multirow[t]{2}{*}{ Ref. } \\
\hline & AA & $\mathrm{AG}$ & GG & $\mathrm{A}$ & $\mathrm{G}$ & & \\
\hline $\operatorname{SCZ}(n=103)$ & 32 & 50 & 18 & 57 & 43 & 68 & \multirow{2}{*}[20,22,24]{} \\
\hline HI $(n=105)$ & 34 & 41 & 25 & 55 & 45 & 66 & \\
\hline$P_{\text {corrected }}=$ & & & & & $0.68^{\mathrm{a}}$ & $0.73^{b}$ & \\
\hline rs 6265 & GG & GA & AA & $\mathrm{G}$ & A & A & \multirow{4}{*}[20-22,24,28-30]{} \\
\hline $\operatorname{SCZ}(n=103)$ & 44 & 50 & 6 & 69 & 31 & 55 & \\
\hline $\mathrm{HI}(\mathrm{n}=105)$ & 65 & 33 & 2 & 8 & 19 & 35 & \\
\hline $\mathrm{P}_{\text {corrected }}=$ & & & & & $0.004^{\mathrm{a}}$ & $0.003^{b}$ & \\
\hline rs1366116 & $\mathrm{CC}$ & $\mathrm{CT}$ & TT & $\mathrm{C}$ & $\mathrm{T}$ & $\mathrm{T}$ & \multirow{3}{*}[26,30]{} \\
\hline $\operatorname{SCZ}(n=260)$ & 26 & 50 & 24 & 51 & 49 & 74 & \\
\hline $\mathrm{HI}(\mathrm{n}=260)$ & 53 & 37 & 10 & 71 & 29 & 47 & \\
\hline $\mathrm{P}_{\text {corrected }}=$ & & & & & $1 \mathrm{E}-49^{\mathrm{a}}$ & $2 E-19^{b}$ & \\
\hline rs3892909 & $\mathrm{CC}$ & $\mathrm{CT}$ & TT & $\mathrm{C}$ & $\mathrm{T}$ & $\mathrm{T}$ & \multirow{4}{*}[26,30]{} \\
\hline $\operatorname{SCZ}(n=260)$ & 33 & 51 & 16 & 58 & 42 & 67 & \\
\hline $\mathrm{HI}(\mathrm{n}=260)$ & 23 & 50 & 27 & 48 & 52 & 77 & \\
\hline $\mathrm{P}_{\text {corrected }}=$ & & & & & $0.00^{\mathrm{a}}$ & $0.01^{\mathrm{b}}$ & \\
\hline rs6330 & GG & GA & AA & $\mathrm{G}$ & A & A & \multirow{4}{*}[27,33]{} \\
\hline $\operatorname{SCZ}(n=200)$ & 43 & 46 & 11 & 66 & 34 & 57 & \\
\hline $\mathrm{HI}(\mathrm{n}=250)$ & 65 & 29 & 6 & 80 & 20 & 35 & \\
\hline $\mathrm{P}_{\text {corrected }}=$ & & & & & $0.00^{\mathrm{a}}$ & $0.00^{\mathrm{b}}$ & \\
\hline rs4839435 & GG & GA & $\mathrm{AA}$ & $\mathrm{G}$ & $\mathrm{A}$ & A & \multirow{3}{*}[27,33]{} \\
\hline $\operatorname{SCZ}(n=225)$ & 24 & 56 & 20 & 52 & 48 & 76 & \\
\hline $\mathrm{HI}(\mathrm{n}=225)$ & 58 & 37 & 5 & 76 & 24 & 42 & \\
\hline
\end{tabular}


Anna Boyajyan et al: : Genetic Variations Associated with Brain Disorders: Focus on Synaptic Plasticity and Apoptosis Regulatory Genes in Schizophrenia, Posttraumatic Stress Disorder and Ischemic Stroke

\begin{tabular}{|c|c|c|c|c|c|c|c|}
\hline \multirow{2}{*}{$\begin{array}{l}\text { SNP ID } \\
P_{\text {corrected }}=\end{array}$} & \multicolumn{3}{|c|}{ Genotypes } & \multicolumn{2}{|c|}{ Alleles } & \multirow{2}{*}{$\begin{array}{l}\text { Carriage } \\
0.00^{\mathrm{b}}\end{array}$} & \multirow[t]{2}{*}{ Ref. } \\
\hline & & & & & $0.00^{\mathrm{a}}$ & & \\
\hline rs11466155 & $\mathrm{CC}$ & $\mathrm{CT}$ & TT & $\mathrm{C}$ & $\mathrm{T}$ & $\mathrm{T}$ & \multirow{4}{*}[27,28,33]{} \\
\hline $\operatorname{SCZ}(n=200)$ & 39.5 & 44 & 16.5 & 62 & 38 & 60.5 & \\
\hline $\mathrm{HI}(\mathrm{n}=225)$ & 20 & 52 & 28 & 46 & 54 & 80 & \\
\hline $\mathrm{P}_{\text {corrected }}=$ & & & & & $0.00^{\mathrm{a}}$ & $0.00^{\mathrm{b}}$ & \\
\hline rs2072446 & $\mathrm{CC}$ & $\mathrm{CT}$ & TT & $\mathrm{C}$ & $\mathrm{T}$ & $\mathrm{T}$ & \multirow{4}{*}[27,28,33]{} \\
\hline $\operatorname{SCZ}(n=200)$ & 34 & 53 & 13 & 61 & 39 & 66 & \\
\hline $\mathrm{HI}(\mathrm{n}=250)$ & 56 & 33 & 11 & 89 & 29 & 47 & \\
\hline$P_{\text {corrected }}=$ & & & & & $0.00^{\mathrm{a}}$ & $0.00^{\mathrm{b}}$ & \\
\hline rs734194 & TT & TG & GG & $\mathrm{T}$ & G & G & \multirow{4}{*}[27,28,33]{} \\
\hline $\operatorname{SCZ}(n=200)$ & 70 & 27 & 4 & 83 & 17 & 31 & \\
\hline $\mathrm{HI}(\mathrm{n}=250)$ & 54 & 37 & 9 & 73 & 27 & 46 & \\
\hline$P_{\text {corrected }}=$ & & & & & $0.01^{\mathrm{a}}$ & $0.02^{\mathrm{b}}$ & \\
\hline rs 11575945 & $\mathrm{CC}$ & $\mathrm{CT}$ & TT & $\mathrm{C}$ & $\mathrm{T}$ & $\mathrm{T}$ & \multirow{4}{*}[25,26,30]{} \\
\hline $\operatorname{SCZ}(n=225)$ & 24 & 56 & 20 & 52 & 48 & 76 & \\
\hline $\mathrm{HI}(\mathrm{n}=225)$ & 58.3 & 36.4 & 5.3 & 76 & 24 & 42 & \\
\hline$P_{\text {nominal }}=$ & & & & & $0.00^{\mathrm{a}}$ & $0.00^{\mathrm{b}}$ & \\
\hline rs 1049550 & GG & GA & $\mathrm{AA}$ & G & A & A & \multirow{4}{*}{ unpublished } \\
\hline $\operatorname{SCZ}(n=225)$ & 30 & 53 & 17 & 56 & 44 & 70 & \\
\hline $\mathrm{HI}(\mathrm{n}=225)$ & 34 & 48 & 18 & 58 & 42 & 66 & \\
\hline $\mathrm{P}_{\text {nominal }}=$ & & & & & $0.64^{\mathrm{a}}$ & $0.42^{\mathrm{b}}$ & \\
\hline rs1057369 & $\mathrm{AA}$ & $\mathrm{AG}$ & GG & A & G & G & \multirow{4}{*}{ [32] } \\
\hline $\operatorname{SCZ}(n=330)$ & 27 & 55 & 18 & 55 & 45 & 73 & \\
\hline $\mathrm{HI}(\mathrm{n}=326)$ & 18 & 53 & 29 & 45 & 55 & 82 & \\
\hline$P_{\text {corrected }}=$ & & & & & $0.00^{\mathrm{a}}$ & $0.02^{\mathrm{b}}$ & \\
\hline rs956572 & GG & GA & $\mathrm{AA}$ & G & A & A & \multirow[b]{3}{*}{ [32] } \\
\hline $\operatorname{SCZ}(\mathrm{n}=330)$ & 34 & 53 & 13 & 60 & 40 & 66 & \\
\hline $\mathrm{HI}(\mathrm{n}=326)$ & 36 & 46 & 18 & 59 & 41 & 64 & \\
\hline$P_{\text {corrected }}=$ & & & & & $1.81^{\mathrm{a}}$ & $1.63^{\mathrm{b}}$ & \multirow{5}{*}{ [32] } \\
\hline rs 1801018 & $\mathrm{AA}$ & AG & GG & A & G & G & \\
\hline $\operatorname{SCZ}(\mathrm{n}=330)$ & 26 & 55 & 19 & 54 & 46 & 74 & \\
\hline $\mathrm{HI}(\mathrm{n}=326)$ & 21 & 57 & 22 & 49 & 51 & 79 & \\
\hline$P_{\text {corrected }}=$ & & & & & $0.37^{\mathrm{a}}$ & $0.35^{\mathrm{b}}$ & \\
\hline
\end{tabular}

${ }^{a}$ Comparison of minor allele frequency between SCZ and HI.

${ }^{\mathrm{b}}$ Comparison of minor allele carriage between $\mathrm{SCZ}$ and $\mathrm{HI}$.

Table 4. Genotype, allele, and minor allele carriage frequencies of the selected SNPs in patients with PTSD and HI.

\begin{tabular}{|c|c|c|c|c|c|c|c|}
\hline \multirow{2}{*}{$\begin{array}{l}\text { SNP ID } \\
\text { rs } 1366116\end{array}$} & \multicolumn{3}{|c|}{ Genotypes } & \multicolumn{2}{|c|}{ Alleles } & \multirow{2}{*}{$\begin{array}{l}\text { Carriage } \\
\mathrm{T}\end{array}$} & \multirow[t]{2}{*}{ Ref. } \\
\hline & $\mathrm{CC}$ & CT & TT & $\mathrm{C}$ & $\mathrm{T}$ & & \\
\hline PTSD (n=87) & 39 & 41 & 20 & 60 & 40 & 61 & \multirow{3}{*}[26,31]{} \\
\hline $\mathrm{HI}(\mathrm{n}=75)$ & 60 & 32 & 8 & 76 & 24 & 40 & \\
\hline $\mathrm{P}_{\text {corrected }}=$ & & & & & $0.01^{\mathrm{a}}$ & $0.02^{\mathrm{b}}$ & \\
\hline rs3892909 & $\mathrm{CC}$ & CT & TT & $\mathrm{C}$ & $\mathrm{T}$ & $\mathrm{T}$ & \multirow{5}{*}[26,31]{} \\
\hline $\operatorname{PTSD}(\mathrm{n}=87)$ & 18 & 52 & 30 & 44 & 56 & 82 & \\
\hline $\mathrm{HI}(\mathrm{n}=75)$ & 20 & 55 & 25 & 47 & 53 & 80 & \\
\hline$P_{\text {corrected }}=$ & & & & & $1.7^{\mathrm{a}}$ & $2.4^{\mathrm{b}}$ & \\
\hline rs11575945 & $\mathrm{CC}$ & CT & TT & $\mathrm{C}$ & $\mathrm{T}$ & $\mathrm{T}$ & \\
\hline PTSD $(n=80)$ & 79 & 17 & 4 & 87.5 & 12.5 & 21 & \multirow{3}{*}[26,31]{} \\
\hline $\mathrm{HI}(\mathrm{n}=75)$ & 71 & 28 & 1 & 85 & 15 & 29 & \\
\hline $\mathrm{P}_{\text {corrected }}=$ & & & & & $1.4^{\mathrm{a}}$ & $0.75^{\mathrm{b}}$ & \\
\hline rs956572 & GG & GA & AA & G & A & A & \multirow{4}{*}{ upublished } \\
\hline $\operatorname{PTSD}(n=132)$ & 14 & 46 & 40 & 37 & 63 & 86 & \\
\hline $\mathrm{HI}(\mathrm{n}=131)$ & 35 & 47 & 18 & 59 & 41 & 65 & \\
\hline$P_{\text {nominal }}=$ & & & & & $0.00^{\mathrm{a}}$ & $0.00^{\mathrm{b}}$ & \\
\hline
\end{tabular}

${ }^{\mathrm{a}}$ Comparison of minor allele frequency between PTSD and HI;

${ }^{\mathrm{b}}$ Comparison of minor allele carriage between PTSD and HI.

Table 5. Genotype, allele, and minor allele carriage frequencies of the selected SNPs in patients with IS and HI.

\begin{tabular}{llllllll}
\hline SNP ID & Genotypes & & Alleles & Carriage & Ref. \\
\hline rs628117 & AA & AG & GG & A & G & G & \\
IS (n=127) & 17 & 47 & 36 & 41 & 59 & 83 & {$[23]$} \\
HI $(\mathrm{n}=128)$ & 37.5 & 40 & 22.5 & 57 & 43 & 62.5 & \\
$\mathrm{P}_{\text {corrected }}=$ & & & & & $0.00^{\mathrm{a}}$ & $0.00^{\mathrm{b}}$ & unpublished \\
rs1366116 & CC & CT & TT & C & T & T & u \\
\hline
\end{tabular}




\begin{tabular}{|c|c|c|c|c|c|c|c|}
\hline \multirow{2}{*}{$\begin{array}{l}\text { SNP ID } \\
\text { IS }(n=172)\end{array}$} & \multicolumn{3}{|c|}{ Genotypes } & \multicolumn{2}{|c|}{ Alleles } & \multirow{2}{*}{$\begin{array}{l}\text { Carriage } \\
59\end{array}$} & \multirow[t]{2}{*}{ Ref. } \\
\hline & 41 & 36 & 23 & 59 & 41 & & \\
\hline HI (n=225) & 53 & 38 & 9 & 72 & 28 & 47 & \\
\hline$P_{\text {corrected }}=$ & & & & & $0.00^{\mathrm{a}}$ & $0.03^{\mathrm{b}}$ & \\
\hline rs3892909 & $\mathrm{CC}$ & CT & TT & $\mathrm{C}$ & $\mathrm{T}$ & $\mathrm{T}$ & \multirow{3}{*}{ unpublished } \\
\hline IS $(n=172)$ & 23 & 50 & 27 & 46 & 54 & 77 & \\
\hline HI $(n=225)$ & 20 & 52 & 28 & 47 & 53 & 80 & \\
\hline$P_{\text {corrected }}=$ & & & & & $1.4^{\mathrm{a}}$ & $1.0^{\mathrm{b}}$ & \multirow{5}{*}{ unpublished } \\
\hline rs 11575945 & $\mathrm{CC}$ & CT & $\mathrm{TT}$ & $\mathrm{C}$ & $\mathrm{T}$ & $\mathrm{T}$ & \\
\hline IS $(n=94)$ & 48 & 42 & 10 & 69 & 31 & 52 & \\
\hline $\mathrm{HI}(\mathrm{n}=110)$ & 75 & 25 & 0 & 88 & 12 & 25 & \\
\hline $\mathrm{P}_{\text {nominal }}=$ & & & & & $0.00^{\mathrm{a}}$ & $0.00^{\mathrm{b}}$ & \\
\hline
\end{tabular}

${ }^{\text {a }}$ Comparison of minor allele frequency between IS and HI.

${ }^{\mathrm{b}}$ Comparison of minor allele carriage between IS and HI.

The distribution of genotypes for all selected SNPs in all study groups complied with $\mathrm{H}-\mathrm{W}$ equilibrium.

Significant associations (either positive or negative) were found between: (1) SCZ and BDNF rs6265, CPLX2 rs1366116, CPLX2 rs3892909, NGF rs6330, NGF rs4839435, NGFR rs734194, NGFR rs11466155, NGFR rs2072446, $A N X A V$ rs11575945, $B A X$ rs 1057369 SNPs; (2) PTSD and $C P L X 2$ rs1366116, BCL2 rs956572 SNPs; (3) IS and NTNG1 rs628117, CPLX2 rs1366116, ANXAV rs11575945 SNPs.

Based on character of association (positive or negative), minor alleles of the BDNF gene rs6265 SNP, CPLX2 rs1366116 SNP, $N G F$ gene rs6330 and rs4839435 SNPs, $N G F R$ gene rs 2072446 SNP, and $A N X A V$ gene rs 11575945 SNP, can be considered risk factors of SCZ, whereas the presence of minor alleles of the CPLX2 gene rs 3892909 , and NGFR gene rs734194 and rs11466155 SNPs, and BAX gene rs1057369 SNP decreases the risk for development of this disorder.

In case of PTSD, the CPLX2 gene rs1366116 SNP and $B C L 2$ gene rs956572 SNP were identified as risk factors for this diseased condition.

Finally, data obtained in case of IS demonstrated that minor alleles of the NTNG1 gene rs628117 SNP, CPLX2 gene rs $1366116 \mathrm{SNP}$ and the $A N X A V$ gene rs $11575945 \mathrm{SNP}$ increase risk for development of stroke.

Brain-derived neurotrophic factor promotes several functions of neurons, modulates neurotransmission, contributes to neuronal growth, survival, and differentiation, and regulates synaptic transmission and cognitive processes [36]. The missense rs6265 SNP of the $B D N F$ gene affects activity-dependent secretion of this neurotrophic factor, memory, and hippocampus functions [37]. Association of the BDNF gene rs6265 SNP with human cortical morphology and bilateral reductions of hippocampus gray matter volumes in the $\mathrm{rs} 6265^{*} \mathrm{~A}$ minor allele carriers compared with the standard rs $6265 \mathrm{G}$ allele homozygotes was demonstrated [38], and a crucial role of this SNP in neuroplasticity alterations in SCZ was revealed [39]. In addition, a relationship of the rs 6265 genotypes with age of onset and the psychotic symptoms of SCZ was observed [40]. Moreover, the $B D N F$ gene rs $6265^{*} \mathrm{~A}$ minor allele was found to associate with increased aggressive behavior in SCZ-affected subjects [41]. However, the results from the meta-analyses of association of the $B D N F$ gene rs6265 SNP with SCZ are controversial, which may reflect the ethnic differences between studied groups [42,43]. According to our data, in Armenian population the rs6265*A minor allele frequency was significantly higher in patients with SCZ than in HI, and the carriers of this allele were overrepresented in patients compared with HI [20-22,24,28-30]. Our results are in concordance with the recent meta-analysis data [42]. We also demonstrated that SCZ is characterized by decreased blood levels of brain-derived neurotrophic factor and that this parameter is lower in the $B D N F$ gene rs $6265^{*} \mathrm{~A}$ minor allele carriers compared to standard rs6265G allele homozygotes [30].

Neuroprotein netrin G1 is an important promoter of neurite outgrowth, regulator of synapse formation and functional activity [44]. Changes in expression levels of the NTNG1 gene were found in a number of diseases characterized by altered synaptic plasticity including SCZ, bipolar disorder, temporal lobe epilepsy, and Rett syndrome [45-49]. Nevertheless, only few studies have evaluated possible association between the NTNG1 gene polymorphisms and diseased conditions. Among those are genome wide association study shown no association between common SNPs of the NTNG1 gene and anorexia nervosa in Europeans [50], study of Zhu et al [51] demonstrated positive association of the NTNG1 gene rs4132604 SNP and the haplotype of rs4132604, rs2218404, and rs1373336 SNPs of this gene with SCZ. In addition, analyzes of 21 SNPs of the NTNG1 gene in 124 Japanese schizophrenic pedigrees revealed association of SCZ with specific haplotypes encompassing alternatively spliced exons, SNPs, and haplotypes clustered in the 5'-region of the $N T N G 1$ gene [45]. Further, Ohtsuki et al investigated 56 tag SNPs of the NTGN1 gene and found association between SCZ and the rs628117 SNP located in intron 9 in the same haplotype block [48]. However, our own data presented in this review demonstrated no association between the rs628117 SNP and SCZ in Armenian population $[20,22,24]$. This discrepancy between our results and those reported by Ohtsuki et al most probably reflects population/ethnic differences between the study groups. Our study for the first time demonstrated the presence of positive association between the rs628117 SNP of the NTNG1 gene and IS [23]. Association between any functional SNP of the NTNG1 gene 
and IS has not been assessed before in any population.

Complexin-2 is a member of complexin family of presynaptic regulatory proteins expressed mainly by excitatory neurons [52]. It has been shown that downregulation of complexin-2 might lead to changes in neurotransmitter release and deficit in synaptic transmission causing significant cognitive and behavioral abnormalities and is implicated in pathogenesis and progression of many diseased conditions characterized by altered cognitive function and behavior [53,54]. In particular, decreased expression levels of this protein in the prefrontal cortex, cerebellum, and hippocampus of patients with SCZ were observed [55], and our own studies revealed decreased production of complexin-2 protein in the blood of SCZ [30] and PTSD $[14,15,18]$ affected subjects. The results obtained in our study with the CPLX2 gene indicated that the rs1366116*T minor allele of this gene was overrepresented in SCZ, PTSD, and IS patients when compared to HI suggesting a positive association of this polymorphism with these diseased conditions [26,30]. While no association between the CPLX2 rs3892909 SNP and PTSD [26,31] or IS [unpublished data] was found, rs $3892909 * \mathrm{~T}$ minor allele of this SNP was more frequent in controls than in SCZ patients $[26,30]$ indicating protective role of this allele against SCZ. It should be noted that these are the first studies exploring association of the CPLX2 gene rs1366116 and rs3892909 SNPs in PTSD and IS in any population. Regarding SCZ, earlier it was shown that current cognitive performance in SCZ patients is modified by a number of CPLX2 variants modulating posttranscriptional gene expression, and that a haplotype covering six SNPs, including rs1366116 and rs3892909, showed high association with this disease [56].

Nerve growth factor and its receptor are other essential mediators of synaptic and morphological plasticity, neuronal growth, survival, and differentiation, especially in the developing brain $[57,58]$. The mature form of nerve growth factor derives from a precursor, which was recently discovered to exert crucial brain functions responsible for mood and cognitive activities [59]. It was reported that in generalized anxiety disorder the blood levels of nerve growth factor increase after successful cognitive behavioral therapy [60]. Moreover, decreased blood levels of this protein in patients with $\mathrm{SCZ}$ were observed [61,62]. Also, it has been shown that chronic cannabis abuse raises NGF serum concentrations in drug-naive patients with $\mathrm{SCZ}$ compared to HI [63]. The results of our study demonstrate a positive association between $\mathrm{SCZ}$ and the rs6330 SNP of the $N G F$ gene as well as the rs11466155 and rs2072446 SNPs of the $N G F R$ gene $[27,28,33]$. Also, a negative association between this disorder and rs4839435 SNP of the NGF gene as well as the rs734194 SNP of the NGFR gene was found [27,28,33]. A non-synonymous rs6330 SNP of the $N G F$ gene is thought to affect intracellular processing and secretion of the NGF protein [64]. Earlier it was shown that the rs6330 SNP is associated with executive dysfunction in patients with Alzheimer's disease, anxiety related traits and affective disorders [65]. However, study of association between SCZ and the rs6330 SNP of the $N G F$ gene has been performed for the first time by us $[27,28,33]$. The same applies to the rs4839435 SNP of the $N G F$ gene $[27,33]$. Another polymorphism of the $N G F$ gene, the rs 12760036 SNP was shown to associate with susceptibility to SCZ in Korean population, and significant differences in the $A G$ and CA haplotype frequencies in the linkage disequilibrium block within the rs12760036 and rs4839435 SNPs between SCZ patients and HI were found indicating the rs $12760036^{*} \mathrm{C}$ minor allele as a risk factor for SCZ in Koreans [66]. Regarding the NGFR gene SNPs, our study for the first time demonstrated association of the rs2072446, rs11466155 and rs734194 SNPs of this gene with SCZ $[27,28,33]$. Notably, the rs 11466155 synonymous SNP of the NGFR gene was not studied before in any diseased condition. It has to be also mentioned that no data relative to functional state of nerve growth factor and its receptor in SCZ either at protein or genetic levels were reported before. The rs2072446 SNP of the NGFR gene and the haplotype containing the rs734194 SNP in the 3'-UTR region of the $N G F R$ gene were recently found to be associated with an increased risk of Alzheimer's disease in Chinese [67].

Annexin-A5 protein is able in the presence of $\mathrm{Ca}^{+2}$ to bind to negatively charged phospholipids, which from the early stages of apoptosis already transfers from the inner to the outer membrane of a cell undergoing apoptosis [68-69]. Annexin-A5 is an important modulator of the process of phagocytosis of apoptotic cells and inflammatory reactions directed to removal of dying cells. Increased levels of this protein induce development of inflammatory reactions [70-72], which are characteristic features of SCZ [22], PTSD [14], and IS [73]. The increased serum levels of this protein were found by us in IS [19] and SCZ [25] and by other research group in SCZ [74], and we also detected the decreased levels of this protein in PTSD [15,18]. The rs11575945 SNP (-1C/T) in the Kozak consensus sequence of the regulatory part of the $A N X A V$ gene plays a key role in the initiation of transcription [75], and the rs $1157945^{*} \mathrm{~T}$ minor allele of this gene correlates with the higher level of synthesis of this protein in the blood [75]. All mentioned above initiated our interest to study this SNP in SCZ, PTSD and IS. In case of IS, the rs 1157945 SNP represents a special interest, since earlier it was shown that the rs1157594 SNP of the $A N X A V$ gene positively associates with cardiovascular disorders [75] and that rs $1157594 * \mathrm{~T}$ minor allele of this SNP increases the risk for development of venous thromboses [76]. While our results on genotyping of the rs1157945 SNP of the $A N X A V$ gene suggest no association between this SNP and PTSD [26,31], we revealed positive association between the rs1157945 SNP and SCZ [25,26,30] as well as the rs1157945 SNP and IS [unpublished data]. These results enable to consider the $\mathrm{T}$ minor allele of the rs1157945 SNP as a risk factor for both SCZ and IS. It has to be mentioned that in the earlier published study the association between SCZ and functional SNP of another representative of the annexin family, the $A N X A 7$ gene, was shown [77]. Also, in our study presented here we found no association between 
the ANXA11 gene functional rs1049550 SNP and SCZ [unpublished], whereas results of our previous investigations indicated increased expression levels of this gene in SCZ [16].

A family of $\mathrm{Bcl}-2$ proteins constitutes one of the most biologically relevant classes of apoptosis regulators acting at the effecter stage of apoptosis, with some members functioning as suppressors of apoptosis and others as promoters of apoptosis. The ultimate vulnerability of cells to diverse apoptotic stimuli is determined by the relative ratio of various pro-apoptotic and anti-apoptotic members of the Bcl-2 family [78,79]. Bcl-2 proper and Bax are members of the $\mathrm{Bcl}-2$ family proteins [80]. Bcl-2 proper is an integral, membrane-associated protein with anti-apoptotic and antioxidative effects [80,81]. Bcl-2 is a major anti-apoptotic protein that inhibits apoptotic and necrotic cell death induced by a diverse set of adverse conditions [82]. Bcl-2 also plays critical roles in neuronal morphogenesis and synaptic plasticity $[83,84]$, and reduced $\mathrm{Bcl}-2$ function is hypothesized to contribute to the impairment of cellular plasticity and resilience in patients with mood disorders [82] BAX is pro-apoptotic member of the family of Bcl-2-related proteins, which has an extensive amino acid homology with Bcl-2 $[85,86]$. Whether the cell will live or die may depend on the level of either protein; while Bcl-2 prevents death, BAX is a death promoter [78-80]. Postmortem studies demonstrated the increased expression level of BAX encoding gene [87] as well as high $\mathrm{BAX} / \mathrm{Bcl}-2$ proteins ratio in the temporal cortex of patients with SCZ [88]. However, it is yet unclear whether these pathologic alterations are genetically determined or caused by other factors. The potential association between SCZ and functional SNPs of genes encoding Bcl-2 family proteins, $B A X$ rs 1057369 and $B C L 2$ rs956572, rs1801018, was assessed for the first time by us [32], and no study has yet explored these SNPs in SCZ in any other population. The same applies to our study on evaluation of association between the $B C L 2$ gene rs956572 SNP and PTSD [unpublished data]. The $B A X$ gene rs1057369 SNP was found by us negatively associated with SCZ: the presence of $B A X$ rs $1057369^{*} \mathrm{G}$ minor allele, especially in homozygous form, was associated with decreased risk of developing SCZ [32]. It has to be mentioned that no data on association of this SNP with any diseased condition has been reported before. Opposite to the $B A X$ gene rs1057369 SNP, the BCL2 gene rs1801018 and rs956572 SNPs have been intensively studied in different conditions. The rs1801018 SNP was mostly found to be associated with oncological disorders [89-92] as well as with poorer clinical outcomes and mortality in patients with traumatic brain injury [93]. The rs956572 SNP was shown to associate with the risk for developing bipolar disorder and was nominated as modulator of the expression of Bcl-2 protein and cellular vulnerability to apoptosis [94]. Preclinical studies show that this SNP exerts functional effects on Bcl-2 expression, as the A homozygous genotype is associated with significantly lower Bcl-2 mRNA expression, 50\% lower Bcl-2 protein levels, and greater cellular sensitivity to stress-induced apoptosis [94]. This SNP was reported to affect gray matter volume in areas known to play key roles in the neurobiology of reward processes and emotion regulation and in the pathophysiology of mood disorders [95]. Also, it was demonstrated that the rs956572 SNP may modulate cognitive function and regional gray matter volume in non-demented elderly men, and affect language performance through its effect on the right middle temporal gyrus [96]. In addition, it was shown that the rs956572 SNP associates with increased anterior cingulate cortical glutamate [97] and disrupted intracellular calcium homeostasis in bipolar I disorder [98] and that abnormal $B C L 2$ gene expression in the AA genotype of the rs 956572 SNP contributes to dysfunctional $\mathrm{Ca}^{2+}$ homeostasis [99]. Our study revealed no association between SCZ and the BCL2 gene rs956572 and rs1801018 SNPs [32] and indicated positive association between the BCL2 gene rs956572 SNP and PTSD [unpublished data].

In summary, with regard to the genes encoding the synaptic plasticity regulatory proteins, we found positive associations between SCZ and the BDNF gene rs6265 SNP, the $N G F$ gene rs6330 and rs4839435 SNPs, as well as the NGFR gene rs2072446 SNP, whereas negative association with this disorder was found for the CPLX2 gene rs3892909 SNP as well as the NGFR gene rs734194 and rs11466155 SNPs. For the CPLX2 gene rs 1366116 SNP positive association with all three diseases was found, and the same association was detected between IS and the NTNG1 gene rs628117 SNP.

In case of the genes encoding the apoptosis regulatory proteins, we found positive associations of the $A N X A V$ gene rs11575945 SNP with both SCZ and IS as well as of the BCL2 gene rs956572 SNP with PTSD. Also, we demonstrated that proapoptotic $B A X$ gene rs1057369 SNP is negatively associated with SCZ.

Since our studies refer to one distinct population (Armenians), the obtained results, particularly those reported by us for the first time, should be replicated in other populations. Not all genes assessed in SCZ have been evaluated by us in PTSD and IS. This should be done in the future studies and more functional SNPs of the selected genes should be investigated in each disorder to have a complete view on the role of genetic predisposition and gene-environment interactions in pathomechanisms of SCZ, PTSD, and IS.

\section{Conclusions}

On the basis of the obtained results we conclude that genetically determined alterations in synaptic plasticity and apoptosis are involved in pathomechanisms of SCZ, PTSD, and IS. The minor $\mathrm{T}$ allele of the CPLX2 gene rs 1366116 polymorphism represents risk factor for all studied diseased conditions indicating important functional significance of this genetic variation in maintenance of synaptic plasticity. Another important conclusion of these studies is that minor alleles of some polymorphic variants of genes, encoding 
synaptic plasticity and apoptosis regulatory proteins, may play a protective role relative to SCZ decreasing the risk for development of this disorder. In summary, our studies emphasize the important contribution of changes in synaptic plasticity and apoptosis regulation to pathomechanisms of SCZ, PTSD, and IS as well as significant input of genetic factors to these changes.

\section{Acknowledgement}

The authors express thanks to administration and physicians of Medical Psychiatric Center, Stress Center of "ArtMed" Medical Center, and Erebouni Medical Center of the Ministry of Health of the Republic of Armenia, Prof. Martin Petrek and Dr. Frantisek Mrazek (Palacky University of Olomouc, Czech Republic). The studies reviewed in this paper were supported by the National Academy of Sciences and the State Committee of Science of the Republic of Armenia, ANSEF (USA) and the International Visegrad Fund (EU).

\section{Competing interests}

The authors declare no conflict of interests.

\section{References}

[1] Tsuang MT, Bar JL, Stone WS, Faraone SV. Gene-environment interactions in mental disorders. World Psychiatry 2004;3(2):73-83.

[2] Dauncey MJ. Genomic and epigenomic insights into nutrition and brain disorders. Nutrients 2013;5(3):887-914.

[3] McCarroll SA, Hyman SE. Progress in the genetics of polygenic brain disorders: significant new challenges for neurobiology. Neuron 2013;80(3):578 -87.

[4] Gejman PV, Sanders AR, Kendler KS. Genetics of schizophrenia: new findings and challenges. Annu Rev Genomics Hum Genet 2011;12:121-44.

[5] Segman RH, Shalev AY. Genetics of Posttraumatic Stress Disorder. CNS Spectr 2003;8(9):693-98.

[6] Hassan A, Markus HS. Genetics and ischaemic stroke. Brain 2000;123(9):1784-812.

[7] Barbato A. Schizophrenia and Public Health. World Health Organization, Geneva, 1998.

[8] Zohar J, Fostick L. Comparison of mortality rates between Israeli veterans with and without post traumatic stress disorder. Eur Neuropsychopharmacol 2014;24:117-24.

[9] Di Carlo A. Human and economic burden of stroke. Age Ageing 2009;38(1):4-5.

[10] Broughton BRS, Reutens DC, Sobey CG. Apoptotic mechanisms after cerebral ischemia. Stroke 2009; 40:e331-9.

[11] Font MA, Arboix A, Krupinsi J. Angiogenesis, neurogenesis and neuroplasticity in ischemic stroke. Curr Cardiol Rev 2010;6(3):238-44
[12] Sumiyoshi T (ed.) Schizophrenia Research: Recent Advances, Nova Science Publishers Inc., USA, 2012.

[13] Chavushyan AS. Annexin-A5 as a marker of apoptotic hyperfunction in schizophrenia. Biol J Armenia 2012;64(4): 91-3.

[14] Boyajyan A, Mkrtchyan G, Hovhannisyan L, Avetyan D. Chapter 5. Alterations in the immune response, apoptosis and synaptic plasticity in posttraumatic stress disorder: molecular indicators and relation to clinical symptoms. In: Durbano F (ed.) New Insights Into Anxiety Disorders, InTech, Croatia, 2013, pp.105-33.

[15] Mkrtchyan GM, Boyajyan AS, Avetyan DG, Sukiasyan SG. The involvement of anomalous apoptosis in disturbance of synaptic plasticity in posttraumatic stress disorder. Zh Nevrol Psikhiatr Im S S Korsakova; 2013;113(1):26-9.

[16] Ghazaryan H. Annexin 11 expression pattern in schizophrenia. Electronic J Natural Sciences (NAS RA) 2013;2(21): 74-6.

[17] Hakobjanyan A, Boyajyan A, Hovsepyan L, Petrek M. Changes of ANXA11 expression level and apoptosis during aging and brain ischemic stroke. Biol J Armenia 2013;65(suppl.1):66-7.

[18] Mkrtchyan GM, Boyadzhyan AS, Avetyan DG, Sukiasyan SG Involvement of anomalous apoptosis in impairments to synaptic plasticity in post-traumatic stress disorder. Neurosci Behav Physiol 2014;44(4):442-6.

[19] Boyajyan A, Tsakanova G, Sim R. Collectins, C3 complement protein, annexin $\mathrm{V}$ and $\mathrm{C}$-reactive protein in acute ischemic stroke: interrelation and implication to upregulated apoptosis and inflammation. Inflamm Cell Signal 2014;1(2): 44-50.

[20] Zakharyan R, Boyajyan A, Arakelyan A, Gevorgyan A, Mrazek F, Petrek M. Functional variants of the genes involved in neurodevelopment and susceptibility to schizophrenia in an Armenian population. Human Immunol 2011;72 (9):746-8.

[21] Zakharyan R, Boyajyan A, Arakelyan A, Mrazek F, Petrek M. The BDNF genetic variant as a risk factor for schizophrenia in Armenian population. Tissue Antigens 2011;77:493.

[22] Boyajyan A., Zakharyan R., Khoyetsyan A. Chapter 11. Molecular and genetic indicators of aberrant immunity and apoptosis in schizophrenia. In: Sumiyoshi $\mathrm{T}$ (ed.) Schizophrenia Research: Recent Advances, Nova Science Publishers Inc., USA, 2012, pp.183-240.

[23] Stepanyan A, Zakharyan R, Boyajyan A. The netrin G1 gene rs628117 polymorphism is associated with ischemic stroke. Neuroscience Lett 2013;549:74-7.

[24] Zakharyan RV, Boyajyan AS. Neurotrophin family gene as potential target for schizophrenia. Electronic $\mathrm{J}$ Natural Sciences (NAS RA) 2013;2(21):82-6.

[25] Boyajyan AS, Chavushyan AS, Zakharyan RV, Mkrtchyan GM. Markers of apoptotic dysfunctions in schizophrenia. Mol Biol (Moscow) 2013;47(4):587-91.

[26] Boyajyan A, Avetyan D, Mkrtchyan G, Sukiasyan S, Zakharyan R, Atshemyan S, Gevorgyan A, Melkumova M, Torosyan S. Population genomics study of molecular pathomechanisms responsible for apoptotic and synaptic plasticity dysfunction in posttraumatic stress disorder and schizophrenia. Armenian J Mental Health 2013;4(Suppl. 1): 66-7. 
[27] Zakharyan R, Atshemyan S, Gevorgyan A, Boyajyan A. Synaptic plasticity regulating genes in schizophrenia. Biol J Armenia 2013;65(Suppl. 1):150-2.

[28] Zakharyan R, Gevorgyan A, Atshemyan S, Torosyan S, Boyajyan A. Genetic risk factors for schizophrenia among synaptogenesis regulating proteins. Armenian J Mental Health 2013;4 (Suppl. 1):91-2.

[29] Zakharyan R, Atshemyan S, Boyajyan A. The role of neuroprotein in schizophrenia pathogenesis. J Neurolog Sci 2013;333(Suppl. 1):e335-6.

[30] Boyajyan A, Chavushyan A, Zakharyan R, Mkrtchyan G, Atshemyan S. Implication of genetic polymorphisms and changes in expression levels of proteins regulating neuronal plasticity and apoptosis in schizophrenia disorder. Eur Psychiatry 2013;28(Suppl. 1):43.

[31] Avetyan DA. Changes in apoptotic rate and synaptic plasticity in patients with posttraumatic stress disorder. Electronic J Natural Sciences (NAS RA) 2013;2(21):70-3.

[32] Pirumyan K, Boyajyan A. Study of association between schizophrenia and functional polymorphisms of genes encoding Bcl-2 family proteins. International Journal of Biological Sciences and Applications, 2014;1(1):28-34.

[33] Zakharyan R, Atshemyan S, Gevorgyan A, Boyajyan A. Nerve growth factor and its receptor in schizophrenia. BBA Clinical, 2014 (in press).

[34] Sambrook J, Russell DW. Molecular Cloning: A Laboratory Manual (3rd edition). Cold Spring Harbor Laboratory Press, USA, 2001

[35] Bunce M, O’Neil CM, Barnado MC, Krausa P, Browning MJ, Morris PJ, Welsh KI. Phototyping: comprehensive DNA typing for HLA-A, B, C, DRB3, DRB4, DRB5 \& DQB1 by PCR with 144 primer mixes utilizing sequence-specific primers (PCR-SSP). Tissue Antigens $1995 ; 46: 355-67$.

[36] Cunha C, Brambilla R, Thomas KL. A simple role for BDNF in learning and memory? Front J Mol Neurosci 2010;3:1.

[37] Egan MF, Kojima M, Callicott JH, Goldberg TE, Kolachana BS, Bertolino A, Zaitsev E, Gold B, Goldman D, Dean M, Lu $\mathrm{B}$, Weinberger DR. The BDNF Val66Met polymorphism affects activity-dependent secretion of BDNF and human memory and hippocampal function. Cell 2003;112(2): $257-69$.

[38] Pezawas L, Verchinski BA, Mattay VS, Callicott JH, Kolachana BS, Straub RE, Egan MF, Meyer-Lindenberg A, Weinberger DR. The brain-derived neurotrophic factor val66met polymorphism and variation in human cortical morphology. J Neurosci 2004;24(45):10099-102.

[39] Buckley PF, Pillai A, Howell KR. Brain-derived neurotrophic factor: findings in schizophrenia. Curr Opin Psychiatry 2011; 24(2):122-7.

[40] Numata S, Ueno S, Iga J, Yamauchi K, Yamauchi K, Hongwei S, Ohta K, Kinouchi S, Shibuya-Tayoshi S, Tayoshi S, Aono M, Kameoka N, Sumitani S, Tomotake M, Kaneda Y, Taniguchi $\mathrm{T}$, Ishimoto $\mathrm{Y}$, Ohmori $\mathrm{T}$. Brain-derived neurotrophic factor (BDNF) Val66Met polymorphism in schizophrenia is associated with age at onset and symptoms. Neurosci Lett 2006;401(1-2):1-5.
[41] Spalletta G, Morris DW, Angelucci F, Rubino IA, Spoletini I, Bria P,Martinotti G, Siracusano A, Bonaviri G, Bernardini S, Caltagirone $\mathrm{C}$, Bossù $\mathrm{P}$, Donohoe G, Gill M, Corvin AP. BDNF Val66Met polymorphism is associated with aggressive behavior in schizophrenia. Eur Psychiatry 2010; 25(6):311-3.

[42] Gratacòs M, González JR, Mercader JM, de Cid R, Urretavizcaya M, Estivill X. Brain-derived neurotrophic factor Val66Met and psychiatric disorders: meta-analysis of case-control studies confirm association to substance-related disorders, eating disorders, and schizophrenia. Biol Psychiatry 2007;61(7):911-22.

[43] Kanazawa T, Glatt SJ, Kia-Keating B, Yoneda H, Tsuang MT. Meta-analysis reveals no association of the Val66Met polymorphism of brain-derived neurotrophic factor with either schizophrenia or bipolar disorder. Psychiatr Genet 2007;17(3):165-70.

[44] Moore SW, Tessier-Lavigne M, Kennedy TE. Netrins and their receptors. Adv Exp Med Biol 2007;621:17-31.

[45] Aoki-Suzuki M, Yamada K, Meerabux J, Iwayama-Shigeno Y, Ohba H, Iwamoto K, Takao H, Toyota T, Suto Y, Nakatani $\mathrm{N}$, Dean B, Nishimura S, Seki K, Kato T, Itohara S, Nishikawa T, Yoshikawa T. A family-based association study and gene expression analyses of netrin-G1 and -G2 genes in schizophrenia. Biol Psychiatry 2005;57(4):382-93.

[46] Borg I, Freude K, Kübart S, Hoffmann K, Menzel C, Laccone F, Firth H, Ferguson-Smith MA, Tommerup N, Ropers HH, Sargan D, Kalscheuer VM. Disruption of Netrin G1 by a balanced chromosome translocation in a girl with Rett syndrome. Eur J Hum Genet 2005;13(8):921-7.

[47] Eastwood SL, Harrison PJ. Decreased mRNA expression of netrin-G1 andnetrin-G2 in the temporal lobe in schizophrenia and bipolar disorder. Neuropsychopharmacology 2008;33(4): 933-45.

[48] Ohtsuki T, Horiuchi Y, Koga M, Ishiguro H, Inada T, Iwata N, Ozaki N, Ujike H, Watanabe Y, Someya T, Arinami T. Association of polymorphisms in the haplotype block spanning the alternatively spliced exons of the NTNG1 gene at 1 p13.3 with schizophrenia in Japanese populations. Neurosci Lett 2008;435(3):194-7.

[49] Pan Y, Liu G, Fang M, Shen L, Wang L, Han Y, Shen D, Wang $\mathrm{X}$. Abnormal expression of netrin-G2 in temporal lobe epilepsy neurons in humans and a rat model. Exp Neurol $2010 ; 224: 340-6$

[50] Wang K, Zhang H, Bloss CS, Duvvuri V, Kaye W, Schork NJ, Berrettini W, Hakonarson H. A genome-wide association study on common SNPs and rare CNVs in anorexia nervosa. Mol Psychiatry 2011;16(9):949-59.

[51] Zhu Y, Yang H, Bi Y, Zhang Y, Zhen C, Xie S, Qin H, He J, Liu L, Liu Y. Positive association between NTNG1 and schizophrenia in Chinese Han population. J Genet 2011;90(3): 499-502.

[52] Harrison PJ, Eastwood SL. Preferential involvement of excitatory neurons in medial temporal lobe in schizophrenia. Lancet 1998;352(9141):1669-73.

[53] Brose N. Altered complexin expression in psychiatric and neurological disorders: cause or consequence? Mol Cells 2008;25(1):7-19. 
[54] Glynn D, Gibson HE, Harte MK, Reim K, Jones S, Reynolds GP, Morton AJ. Clorgyline-mediated reversal of neurological deficits in a Complexin 2 knockout mouse. Hum Mol Genet 2010;19(17): 3402-12.

[55] Eastwood SL, Harrison PJ. Hippocampal synaptic pathology in schizophrenia, bipolar disorder and major depression: a study of complexin mRNAs. Mol Psychiatry 2000;5:425-32.

[56] Begemann M, Grube S, Papiol S, Malzahn D, Krampe H, Ribbe K, Friedrichs H, Radyushkin KA, El-Kordi A, Benseler F, Hannke K, Sperling S, Schwerdtfeger D, Thanhäuser I, Gerchen MF, Ghorbani M, Gutwinski S, Hilmes C, Leppert R, Ronnenberg A, Sowislo J, Stawicki S, Stödtke M, Szuszies C, Reim K, Riggert J, Eckstein F, Falkai $\mathrm{P}$, Bickeböller $\mathrm{H}$, Nave KA, Brose N, Ehrenreich $\mathrm{H}$. Modification of cognitive performance in schizophrenia by complexin 2 gene polymorphisms. Arch Gen Psychiatry 2010;67(9):879-88.

[57] McAllister AK, Katz LC, Lo DC. Neurotrophins and synaptic plasticity. Annu Rev Neurosci 1999;22:295-318.

[58] Buckley PF, Mahadik S, Pillai A, Terry JrA. Neurotrophins and schizophrenia. Schizophr Res 2007;94:1-11.

[59] Stanisz AM, Stanisz JA. Nerve growth factor and neuroimmune interactions in inflammatory diseases. Ann N Y Acad Sci 2000;917:268-72.

[60] Jockers-Scherubl MC, Zubraegel D, Baer T, Linden M, Danker-Hopfe H, Schulte-Herbruggen O, Neu P, Hellweg R. Nerve growth factor serum concentrations rise after successful cognitive-behavioural therapy of generalized anxiety disorder. Prog Neuropsychopharmacol Biol Psychiatry 2007;31(1):200-4.

[61] Xiong P, Zeng Y, Zhu Z, Tan D, Xu F, Lu J, Wan J, Ma M. Reduced NGF serum levels and abnormal P300 event-related potential in first episode schizophrenia. Schizophr Res 2010;119(1-3):34-9.

[62] Xiong P, Zeng Y, J Wan J, Xiaohan DH, Tan D, Lu J, Xu F, Li HY, Zhu Z, Ma M. The role of NGF and IL-2 serum level in assisting the diagnosis in first episode schizophrenia. Psychiatry Res 2011;189(1):72-6.

[63] Jockers-Scherubl MC, Matthies U, Danker-Hopfe H, Lang UE, Mahlberg R, Hellweg R. Chronic cannabis abuse raises nerve growth factor serum concentrations in drug-naive schizophrenic patients. J Psychopharmacol 2003;17(4):43945.

[64] Syed Z, Dudbridge F, Kent L. An investigation of the neurotrophic factor genes GDNF, NGF, and NT3 in susceptibility to ADHD. Am J Med Genet B 2007;144B(3): 375-8.

[65] Di Maria E, Giorgio E, Uliana V, Bonvicini C, Faravelli F, Cammarata S, Novello MC, Galimberti D, Scarpini E, Zanetti O, Gennarelli M, Tabaton M. Possible influence of a non-synonymous polymorphism located in the NGF precursor on susceptibility to late-onset Alzheimer's disease and mild cognitive impairment. J Alzheimers Dis 2012;29(3): 699-705.

[66] Park JK, Lee SM, Kang WS, Kim SK, Cho AR. NGF polymorphisms and haplotypes are associated with schizophrenia in Korean population. Mol Cell Toxicol 2011;7:375-80
[67] Cheng HC, Sun Y, Lai LC, Chen SY, Lee WC, Chen JH, Chen TF, Chen HH, Wen LL, Yip PK, Chu YM, Chen WJ, Chen YC. Genetic polymorphisms of nerve growth factor receptor (NGFR) and the risk of Alzheimer's disease. J Negat Results Biomed 2012;11:5

[68] Gerke V, Moss SE. Annexins: from structure to function. Physiol Rev 2002;82(2):331-71

[69] Boersma HH, Kietselaer BL, Stolk LM, Bennaghmouch A, Hofstra L, Narula J, Heidendal GA, Reutelingsperger CP. Past, present, and future of annexin A5: from protein discovery to clinical applications. J Nucl Med 2005;46(12):2035-50.

[70] Munoz L, Frey B, Pausch F, Baum W, Mueller R, Brachvogel B, Poschl E, Rodel F, von der Mark K, Herrmann M, Gaipl U. The role of annexin A5 in the modulation of the immune response against dying and dead cells. Curr Med Chem 2007;14(3):271-7.

[71] Gaipl US, Munoz LE, Rodel F, Pausch F, Frey B, Brachvogel $\mathrm{B}$, von der Mark K, Poschl E. Modulation of the immune system by dying cells and the phosphatidylserine-ligand annexin A5. Autoimmunity 2007;40(4):254-9.

[72] Martin M, Leffler J, Blom AM. Annexin A2 and A5 serve as new ligands for C1Q on apoptotic cells. J Biol Chem 2012; 287(40):33733-44.

[73] Di Napoli M, Arakelyan A, Boyajyan A, Godoy A, Papa F. Chapter 2. The acute phase inflammatory response in stroke: systemic inflammation and neuroinflammation. In: Pitzer JA (ed.) Progress in Inflammation Research, Nova Science Publishers Inc., USA, 2005, pp.95-145.

[74] Francesconi LP, Ceresér KM, Mascarenhas R, Stertz L, Gama $\mathrm{CS}$, Belmonte-de-Abreu P. Increased annexin-V and decreased TNF-alpha serum levels in chronic-medicated patients with schizophrenia. Neurosci Lett 2011;502(3):143- 6 .

[75] González-Conejero R, Corral J, Roldán V, Martínez C, Marín F, Rivera J, Iniesta JA, Lozano ML, Marco P, Vicente V. A common polymorphism in the annexin $\mathrm{V}$ Kozak sequence $(-1 C>T)$ increases translation efficiency and plasma levels of annexin $\mathrm{V}$, and decreases the risk of myocardial infarction in young patients. Blood 2002;100(6):2081-6.

[76] Van Heerde WL, DeGroot PG, Reutelingsperger CPM. The complexity of the phospholipid binding protein Annexin V. Thromb Haemost 1995;73(2):172-9.

[77] Liu CM, Fann CS, Chen CY, Liu YL, Oyang YJ, Yang WC, Chang CC, Wen CC, Chen WJ, Hwang TJ, Hsieh MH, Liu CC, Faraone SV, Tsuang MT, Hwu HG. ANXA7, PPP3CB, DNAJC9, and ZMYND17 genes at chromosome 10q22 associated with the subgroup of schizophrenia with deficits in attention and executive function. Biol Psychiatry 2011;70(1):51-8.

[78] Roset R, Ortet L, Gil-Gomez G. Role of Bcl-2 family members on apoptosis: what we have learned from knock-out mice. Front Biosci 2007;12:4722-30.

[79] Youle RJ, Strasser A.The BCL-2 protein family: opposing activities that mediate cell death. Nat Rev Mol Cell Biol 2008;9(1):47-59.

[80] Korsmeyer SJ, Shutter JR, Veis DJ, Merry DE, Oltvai ZN. Bcl2/Bax: a rheostat that regulates an anti-oxidant pathway and cell death. Semin Cancer Biol 1993;4(6):327-32. 
[81] Yang J, Liu X, Bhalla K, Kim CN, Ibrado AM, Cai J, Peng TI, Jones DP, Wang X. Prevention of apoptosis by Bcl-2: release of cytochrome $\mathrm{c}$ from mitochondria blocked. Science 1997;275(5303):1129-32.

[82] Chen G, Manji HK. The extracellular signal-regulated kinase pathway: An emerging promising target for mood stabilizers. Curr Opin Psychiatry 2006;19:313-23.

[83] Chen DF, Schneider GE, Martinou JC, Tonegawa S. Bcl-2 promotes regeneration of severed axons in mammalian CNS. Nature 1997;385:435-9.

[84] Jonas E. Bcl-xl regulates synaptic plasticity. Mol Interv 2006;6:208-22

[85] Oltwai ZN, Milliman CL, Korsemeyer SJ. Bcl2 heterodimers in vivo with a conserved homolog Bax, that accelerates programmed cell death. Cell 1993;74:609-19.

[86] Surhone LM, Tennoe MT, Henssonow SF. Bcl-2-associated X Protein. Beau Bassin: Betascript Publishing, 2011.

[87] Jarskog LF, Selinger ES, Lieberman JA, Gilmore JH. Cortical $\mathrm{Bcl} 2$ protein expression and apoptotic regulation in schizophrenia. Biol Psychiatry 2000;48:641-50.

[88] Jarskog LF, Selinger ES, Lieberman JA, Gilmore JH. Apoptotic proteins in the temporal cortex in schizophrenia: high $\mathrm{Bax} / \mathrm{Bcl} 2$ ratio without caspase-3 activation. Am J Psychiatry 2004;161:109-15.

[89] Milani L, Gupta M, Andersen M, Dhar S, Fryknäs M, Isaksson A, Larsson R, Syvänen AC. Allelic imbalance in gene expression as a guide to cis-acting regulatory single nucleotide polymorphisms in cancer cells. Nucleic Acids Res 2007;35(5):34.

[90] Kim DH, Xu W, Ma C, Liu X, Siminovitch K, Messner HA, Lipton JH. Genetic variants in the candidate genes of the apoptosis pathway and susceptibility to chronic myeloid leukemia. Blood 2009;113(11):2517-25.

[91] Eun YG, Hong IK, Kim SK, Park HK, Kwon S, Chung DH, Kwon KH. Polymorphism (rs1801018, Thr7Thr) of BCL2 is associated with papillary thyroid cancer in Korean population. Clin Exp Otorhinolaryngol 2011;4(3):149-54.
[92] Gu S, Wu Q, Zhao X, Wu W, Gao Z, Tan X, Qian J, Chen H, Xie Y, Jin L, Han B, Lu D. Association of CASP3 polymorphism with hematologic toxicity in patients with advanced non-small-cell lung carcinoma treated with platinum-based chemotherapy. Cancer Sci 2012;103(8):1451-9.

[93] Hoh NZ, Wagner AK, Alexander SA, Clark RB, Beers SR, Okonkwo DO, Ren D, Conley YP. BCL2 genotypes: functional and neurobehavioral outcomes after severe traumatic brain injury. J Neurotrauma 2010;27(8):1413-27.

[94] Manji HK. Bcl-2: A key regulator of affective resilience in the pathophysiology and treatment of severe mood disorders. Biol Psychiatry 2008;63(Suppl 1):243S.

[95] Yuan P, Baum AE, Zhou R, Wang Y, Laje G, McMahon FJ. Bcl-2 polymorphisms associated with mood disorders and antidepressant-responsiveness regulate $\mathrm{Bcl}-2$ gene expression and cellular resilience in human lymphoblastoid cell lines. Biol Psychiatry 2008;63(Suppl 1):63S.

[96] Salvadore G, Nugent AC, Chen G, Akula N, Yuan P, Cannon DM, Zarate CA Jr, McMahon FJ, Manji HK, Drevets WC. Bcl-2 polymorphism influences gray matter volume in the ventral striatum in healthy humans. Biol Psychiatry 2009;66(8):804-7.

[97] Liu ME, Huang CC, Hwang JP, Yang AC, Tu PC, Yeh HL, Hong CJ, Liou YJ, Chen JF, Lin CP, Tsai SJ. Effect of Bcl-2 rs956572 SNP on regional gray matter volumes and cognitive function in elderly males without dementia. Age (Dordr) 2013;35(2):343-52.

[98] Soeiro-de-Souza MG, Salvadore G, Moreno RA, Otaduy MC, Chaim KT, Gattaz WF, Zarate CA Jr, Machado-Vieira R. Bcl-2 rs956572 polymorphism is associated with increased anterior cingulate cortical glutamate in euthymic bipolar I disorder. Neuropsychopharmacology 2013;38(3):468-75.

[99] Uemura T, Green M, Corson TW, Perova T, Li PP, Warsh JJ. Bcl-2 SNP rs956572 associates with disrupted intracellular calcium homeostasis in bipolar I disorder. Bipolar Disord 2011;13(1):41-51 